\title{
De verstaanbaarheid van "Standaardnederlandsen" voor vergevorderde NVT-studenten in Centraal-
}

\section{Europa}

\author{
The Intelligibility of Standard Dialects of Dutch \\ for Advanced Students of Dutch as a Foreign Language in Central \\ Europe
}

Sofie Royeaerd

\begin{abstract}
Increasingly, students of Dutch as a Foreign Language come into contact with other varieties of Dutch than are taught at university. If we want to prepare them for real life language situations that are pluralistic and complex, it is necessary to get a picture of the intelligibility problems that they experience and the causes that underlie them. In this article, our focus is on the intelligibility of standard dialects of Dutch. We also briefly discuss the result of a distinction test, in which students were asked to identify the national variety (Belgian Dutch or Netherlandic Dutch). Following Grondelaers, Van Hout \& Van Gent (2016), we distinguish four dialects, namely the virtual ("Neutral Standard Dutch") and the vital standard language ("Teacher Dutch") in both national varieties.

By means of an opinion test, the intelligibility of 12 audio fragments was assessed by 42 master students of Dutch in Central Europe. The stimuli representing "Neutral Standard Dutch" received significantly higher scores than the "Teacher Dutch" stimuli, even though the average speech rate was comparable and the lexical difficulty of the former was estimated to be higher. This may indicate that other elements, such as pronunciation and prosodic features, are the main factors in explaining the difference in intelligibility scores. Further research with a larger selection of stimuli, manipulated to minimize the number of variables, is, however, needed to map this out. Nonetheless, the preliminary results of this small experiment suggest that both teachers and students of Dutch as a Foreign Language could benefit from a better, researchbased, description of the "vital" standard dialects of Dutch, which at the moment seems to be lacking.
\end{abstract}




\section{Keywords}

standard language; Teacher Dutch; Dutch as a Foreign Language; language variation; intelligibility

\section{Inleiding}

Ik reisde met de trein en een vrouw begon mij iets te vertellen. Ze sprak waarschijnlijk in een dialect want ik kon [...] bijna niets verstaan. Ik heb alleen begrepen dat ze over de verkeerssituatie klaagde. Ze merkte wellicht niet dat ik haar niet versta (ik knikte en lachte de hele tijd) en klaagde en klaagde. ${ }^{1}$

Aan het woord is een student Nederlands uit Brno die in het kader van een uitwisselingsprogramma zes maanden in Leiden verbleef. Het is een herkenbare situatie waar niet uitsluitend anderstaligen in Nederland en Vlaanderen tegenaan lopen.

Op reis, tijdens een studieverblijf in de Lage Landen maar ook bijvoorbeeld als telefonist in een callcenter in het thuisland, komen (voormalige) studenten Nederlands als Vreemde Taal (NVT) in aanraking met andere variëteiten dan ze kregen aangeleerd. Dat ze moeilijkheden ondervinden met dialecten, zoals de student in de trein, is niet meer dan normaal, maar hoe zit het met de verstaanbaarheid van andere variëteiten van het Nederlands?

In de steeds groeiende stroom aan publicaties over het verschijnsel "tussentaal" wordt herhaaldelijk gewezen op problemen van NT2- en NVT-studenten met de omgangstaal van Vlamingen (zie bijv. Bolten 2004 en Hiligsmann 2010). Zoals in verschillende publicaties wordt aangekaart, werd de verstaanbaarheid van tussentaal voor anderstaligen echter nog niet empirisch onderzocht (zie bijv. Absillis, Jaspers \& Van Hoof 2012: 23 en Kloots \& Gillis 2012: 233), terwijl daar vanuit het NT2- en NVT-onderwijs wel vraag naar is (zie bijv. Lybaert 2016). Over het algemeen wordt aangenomen dat de Nederlands-Nederlandse omgangstaal minder verstaanbaarheidsproblemen oplevert omdat deze variëteit dichter aanleunt bij de standaardtaal die in het onderwijs Nederlands als Tweede en Vreemde Taal doorgaans als model functioneert. Maar ook deze hypothese werd vooralsnog niet door onderzoek gestaafd.

Daarnaast kan men zich de vraag stellen hoe anderstaligen omgaan met de variatie binnen de Nederlandse standaardtaal. Die variatie is niet beperkt tot de drie natiolecten (Nederlands-, Belgisch- en Surinaams-Nederlands), zoals Grondelaers, Van Hout \& Van Gent (2016) laten zien. Zij onderscheiden zowel binnen het Nederlands- als het BelgischNederlands naast een "virtuele" ook een "praktische" standaard die met name op vlak van de uitspraak gekenmerkt wordt door sociale en regionale variatie. Aan de hand van

1 Reactie (anoniem), online vragenlijst verstuurd naar masterstudenten Nederlands in Brno (tijdens/na hun Erasmusverblijf in Nederland en Vlaanderen), april 2017. 
een opinietest werd onderzocht in welke mate vergevorderde NVT-leerders deze verschillende "Standaardnederlandsen" menen te verstaan.

Eerst ga ik in de op de vraag welke oorzaken ten grondslag kunnen liggen aan verstaanbaarheidsproblemen. Vervolgens onderscheid ik vier soorten Standaardnederlands, die vertegenwoordigd zijn in het stimulusmateriaal dat aan 42 proefpersonen werd voorgelegd. Nadat ik de samenstelling van het testmateriaal en het profiel van de respondenten heb toegelicht, bespreek ik de resultaten van de verstaanbaarheidstest. Behalve deze opinietest kregen de respondenten ook een distinctietest voorgelegd om na te gaan of zij in staat zijn om een correct onderscheid te maken tussen de Belgische en Nederlandse standaardvariëteit.

\section{Oorzaken verstaanbaarheidsproblemen}

Verstaanbaarheid kan worden opgevat als het vermogen om "in de geluidsstroom woorden in een specifieke volgorde [te herkennen]" (Kloots en Gillis, 2012: 229). Dat een boodschap wordt verstaan, betekent niet dat die ook wordt begrepen: daarvoor moet de ontvanger ook "de bedoeling van de spreker vatten", aldus Kloots en Gillis. In hun bijdrage "Bang voor Babel. De verstaanbaarheid van tussentaal" situeren zij de oorzaak van verstaanbaarheidsproblemen op drie niveaus: dat van de productie, de transmissie en de perceptie.

Behalve de variëteit die de spreker gebruikt, en alles wat daarmee samenhangt zoals lexicon en - zeker niet verwaarloosbaar - intonatie, zijn er uiteraard andere factoren die verstaanbaarheid in de weg kunnen staan, bijvoorbeeld een slordige articulatie of hoog spreektempo. Onderzoek wijst uit dat deze laatste factor niet te onderschatten is, zoals ook Leen Impe (2010) aanstipt in haar proefschrift over de wederzijdse verstaanbaarheid van nationale en regionale variëteiten van het Nederlands. Zij verwijst naar een onderzoek van Verhoeven, De Pauw \& Kloots (2004) waaruit blijkt dat het spreektempo van Nederlanders over het algemeen beduidend hoger ligt dan dat van Vlamingen (Impe 2010: 32). Ook een factor van belang is attitude, zo beklemtonen Kloots en Gillis (2012, passim). Is de spreker geneigd zich aan te passen aan zijn gesprekspartner zodat zijn boodschap wordt begrepen?

Op het niveau van de transmissie kunnen zich eveneens een aantal problemen voordoen die onverstaanbaarheid in de hand werken, zoals achtergrondlawaai en de geluidskwaliteit van gesprekken via Skype of de telefoon. Omdat een informele variëteit als tussentaal in tegenstelling tot de standaardtaal meestal in informelere settings te horen is, waar vaak sprake is van achtergrondgeluid, kan dit in negatieve zin de verstaanbaarheid ervan beïnvloeden (vgl. Kloots en Gillis 2012: 232).

"Attitudinele aspecten" treffen we niet alleen aan op het niveau van de productie, maar ook op dat van de perceptie. Is de luisteraar bereid om "een (extra) inspanning

2 Vgl. Geeraerts (2017). Hij heeft het in zijn bijdrage overigens alleen over Belgisch- en Nederlands-Nederlands (bij hem zonder koppelteken geschreven). 
[te] leveren om de spreker te (leren) verstaan"? (idem: 234) Of een boodschap verstaan en begrepen wordt hangt uiteraard ook af van de talige kennis van de in ons geval anderstalige ontvanger. Dit behelst niet alleen de actieve en passieve woordenschat van de luisteraar maar ook bijvoorbeeld in hoeverre hij zich het klanksysteem van het Nederlands heeft eigen gemaakt (idem: 232).

Er zijn dus een groot aantal factoren die een rol spelen in het complexe proces dat verstaanbaarheid is en die het bijzonder moeilijk maken een evenwichtig corpus aan te leggen, variabelen te isoleren en een homogene groep testpersonen samen te stellen.

\section{Profiel proefpersonen}

Om een zo uniform mogelijke groep proefpersonen af te bakenen, werd de verstaanbaarheids- en distinctietest voorgelegd aan masterstudenten Nederlands in de regio CentraalEuropa. 42 studenten van 7 verschillende vakgroepen ${ }^{3}$ vulden een online vragenlijst in en legden beide tests af. Het gaat om moedertaalsprekers van het Hongaars of een Slavische taal, die naar eigen zeggen Engels op een hoog niveau beheersen. 13 respondenten gaven ook aan over een goede kennis van het Duits te beschikken. ${ }^{4}$

De overgrote meerderheid van de studenten $^{5}$ schatte zijn of haar niveau van het Nederlands in op B2 of C1 volgens het Gemeenschappelijk Europees Referentiekader voor Moderne Vreemde Talen (ERK). Dat zijn in de genoemde regio doorgaans de eindniveaus van respectievelijk de Bachelor- en Masteropleiding. Deze (ver)gevorderde studenten zijn volgens de descriptoren van het $\mathrm{ERK}^{6}$ in staat om "opnamen in standaarddialect" te verstaan "die veel worden aangetroffen in het sociale, beroeps- of onderwijsleven". C1-studenten kunnen zelfs "een breed scala van opgenomen en uitgezonden geluidsmateriaal verstaan, met inbegrip van enig niet-standaardtaalgebruik". Wat dit laatste precies inhoudt, wordt niet toegelicht. Ook over de kwestie welke variëteit of variëteiten men tot de standaard moet rekenen, kan worden gediscussieerd.

35 respondenten van de Eötvös Loránd Universiteit in Boedapest; 3 respondenten van de Universiteit Karoli Gaspar Reformatus Egyetem in Boedapest; 7 respondenten van de Universiteit Debrecen; 2 respondenten van de Comeniusuniversiteit in Bratislava; 7 respondenten van de Masaryk Universiteit in Brno; 5 respondenten van de Palacký Universiteit in Olomouc, 3 respondenten van de Karelsuniversiteit in Praag; 10 respondenten van de Universiteit van Wrocław.

4 In beide gevallen werd gevraagd of zij deze talen minstens op B2-niveau beheersen.

5 Opvallend is dat slechts twee respondenten, gevraagd naar hun taalniveau, de optie "Dat weet ik niet" aanvinkten. Behalve twee respondenten, die niveau B1 opgaven, beschikken alle andere respondenten naar eigen zeggen over niveau B2 of hoger (22 respondenten B2-niveau, 15 respondenten C1-niveau en 1 respondent C2-niveau).

6 Zie Gemeenschappelijk Europees referentiekader voor moderne vreemde talen: leren, onderwijzen, beoordelen. Supplement met nieuwe descriptoren (Nederlandse vertaling, 2018), online raadpleegbaar via taalunieversum.org. 


\section{Nederlandse en Belgische (standaard)variëteiten}

Grondelaers, Van Hout en Van Gent (2016) stellen dat klassieke criteria om standaardvariëteiten af te bakenen aan herziening toe zijn: zij verwerpen de bestaande criteria niet, maar pleiten voor een uitbreiding ervan. ${ }^{7}$ Ook "vitale" variëteiten, die per definitie variatie vertonen, moeten in aanmerking kunnen komen voor het etiket "standaardtaal", vinden zij. (idem, passim) Zij onderscheiden zes variëteiten, drie Belgische en drie Nederlandse, die schematisch als volgt kunnen worden weergegeven:

\begin{tabular}{|l|l|l|c|}
\hline \multicolumn{1}{|c|}{$\begin{array}{c}\text { Standaardtaal- } \\
\text { statuut }\end{array}$} & Belgisch-Nederlands (BN) & \multicolumn{1}{|c|}{$\begin{array}{c}\text { Nederlands-Nederlands } \\
\text { (NN) }\end{array}$} & Afkorting \\
\hline "virtuele" standaard & Neutraal BN-Nederlands & Neutraal NN-Nederlands & ST+ \\
\hline "praktische" standaard & "Lerarennederlands" & "Lerarennederlands" & ST- \\
\hline "opkomende" standaard & Tussentaal & Hun-Nederlands & OT \\
\hline
\end{tabular}

Tabel 1 - Bovenregionale variëteiten van het Belgisch-Nederlands en Nederlands-Nederlands, naar Grondelaers, Van Hout en Van Gent (2016)

Het neutrale BN-Nederlands, door de auteurs "Neutral VRT-Dutch" genoemd, vertegenwoordigt de variëteit die onder meer door nieuwslezers op de Vlaamse openbare omroep gesproken wordt. Dit Journaalnederlands, om de term van Cajot (2012, passim) te gebruiken, is weliswaar de enige Belgische variëteit die in Vlaanderen traditioneel prestige geniet, maar komt amper in spontane, niet-voorbereide spraak voor. Daarom noemen de auteurs van het artikel hem "virtueel" en zelfs een "zombiestandaard" (Grondelaers, Van Hout \& Van Gent 2016: 143-144). Hoewel het geen levendige variëteit is, bekleedt hij - wellicht onder invloed van wat Van Hoof en Jaspers (2012) "hyperstandaardisering" noemen - een sterke positie in het Vlaamse taallandschap en wordt onomstreden als standaard erkend.

De Nederlandse tegenhanger wordt in het Engelstalige artikel "Neutral Netherlandic Standard Dutch" genoemd. Het gaat net als bij het Journaalnederlands om een variatieloze en virtuele variëteit die in de Nederlandse taalrealiteit zelden voorkomt.

De rol van vitale standaard wordt volgens de auteurs vervuld door wat ze hier "Lerarennederlands" ("Teacher Dutch") noemen. Dat doen ze op basis van onderzoek naar het taalgebruik van leraren in het Corpus Gesproken Nederlands (CGN). Daaruit blijkt dat de spraak van de overgrote meerderheid van de Nederlandse en Vlaamse leraren gekenmerkt wordt door een regionaal accent. In het geval van het Nederlandse "Lerarennederlands" zien we ook sociale variatie, met name Poldernederlands. Deze open uitspraak van een aantal tweeklanken is inmiddels wijdverbreid en geaccepteerd

7 Tegenover de traditionele criteria (het idee dat standaardtalen "uniform/common", "overtly prestigious" en "explicietely codified" moeten zijn) stellen Grondelaers, Van Hout en Van Gent (2016) nieuwe criteria ("perceptually harmonious", "covertly prestigious" en "media-licensed") en voegen hier nog twee criteria aan toe ("vital" en "multi-indexical").

8 De termen in het artikel werden gedeeltelijk overgenomen. De afkortingen zijn van mij. ST staat voor standaardtaal, OT voor omgangstaal. 
(Grondelaers, Van Hout \& Van Gent 2016: 124). Karakteriserend voor de Belgische variëteit is dat we naast een regionaal accent ook vaak "niet-standaardtalige fonologie" aantreffen, zoals "t-deletie in korte functiewoorden" (idem: 122, mijn vertaling, sr), bijvoorbeeld "nie" en "da" in plaats van "niet" en "dat".

De laatste twee variëteiten, die nog niet in aanmerking komen voor het etiket "standaardtaal", zijn de Vlaamse "tussentaal" en wat de auteurs "hun-Nederlands" noemen. Het gaat om variëteiten die naast regionale en sociale accenten ook gekenmerkt worden door niet-standaardtalige morfosyntaxis. In het geval van tussentaal kunnen we daarbij denken aan het "ge-paradigma", in verband met de Nederlandse variëteit noemen de auteurs twee voorbeelden: het gebruik van "hun" voor de derde persoon meervoud in subjectsvorm (standaard "ze") en "perifrastisch doen" (idem 2016: 125).

De auteurs zijn er zich van bewust dat dit model een enigszins misleidend beeld geeft van het taallandschap in de Lage Landen. Zo kan er eigenlijk geen categorisch onderscheid gemaakt worden tussen de Belgische variëteit van het Lerarennederlands en de tussentaal (Grondelaers, Van Hout \& Van Gent 2016: 126); die vormen namelijk een continuüm. Bovendien is de variatiebreedte van tussentaal veel groter dan die van het hun-Nederlands. Ook het onderscheid dat wordt gemaakt tussen de virtuele en praktische standaard is enigszins kunstmatig. Bovendien komt de neutrale, uniforme variant van NN in de praktijk amper voor (ibidem, vgl. ook Beheydt 2011: 106).

Niettemin lijkt het zinvol om bij een onderzoek naar de verstaanbaarheid van het Standaardnederlands niet alleen een onderscheid te maken tussen de Nederlandse en Belgische variëteit, maar ook tussen een virtuele ("hogere") en praktische ("lagere") variëteit binnen de Nederlandse standaardtaal. Uit een kleine navraag bij uitwisselingsstudenten uit Brno die één of meerdere semesters in de Lage Landen verbleven, kwam bijvoorbeeld naar voren dat zij - hoewel zij over het algemeen weinig of geen moeite hadden om de docenten te verstaan ${ }^{10}$ - toch een verschil gewaarwerden tussen de spraak van docenten binnen en buiten de opleiding neerlandistiek. Zo schreef een uitwisselingsstudent in Gent:

De docenten die zich met Nederlands [bezighouden] zijn heel goed verstaanbaar. Docenten die bijvoorbeeld lessen in geschiedenis geven, hebben [de] neiging [...] in tussentaal te spreken en daardoor zijn ze ook minder verstaanbaar. ${ }^{11}$

Dat de docenten in kwestie "tussentaal" spreken tijdens de colleges is natuurlijk een inschatting van de student. Het is goed mogelijk dat niet-neerlandici aan de universiteit,

9 Dit laatste verschijnsel illustreren Grondelaers, Van Hout \& Van Gent (2016: 125) met het volgende voorbeeld: "Doe jij de afwas, dan doe ik de vaatwasser uitruimen."

10 Online vragenlijst verstuurd naar masterstudenten Nederlands in Brno (tijdens/na hun Erasmusverblijf in Nederland en Vlaanderen), april 2017. De verstaanbaarheid van docenten tijdens de colleges werd overigens over het algemeen heel hoog ingeschat. De zes respondenten gaven een gemiddelde score van 4,7 voor de verstaanbaarheid van de docenten aan het begin van hun Erasmusverblijf en een 5 aan het einde van hun Erasmusverblijf.

11 Reactie (anoniem), online vragenlijst verstuurd naar masterstudenten Nederlands in Brno (tijdens/na hun Erasmusverblijf in Nederland en Vlaanderen), april 2017. 
net als de leraren in het bovengenoemde CGN-onderzoek, een "lagere" vorm van standaardtaal gebruiken. Dit verschijnsel lijkt zich overigens niet enkel bij Vlaamse docenten te manifesteren want ook een uitwisselingsstudent in Leiden merkte op:

De docenten die in het kader van de Dutch Studies onderwezen waren [...] heel goed verstaanbaar. Vanaf het begin al. Wat echter de andere docenten betreft waren ze niet zo goed te verstaan $\left[\ldots . .\right.$. . Dit is gedurende het semester verbeterd. ${ }^{12}$

Uit dit anekdotische bewijs kunnen we natuurlijk geen veralgemenende conclusies trekken. Bovendien is het moeilijk om te achterhalen of het verschil in verstaanbaarheid te maken heeft met de minder vertrouwde onderwerpen die werden behandeld, dan wel met de variëteit die de docenten hanteerden. Daarom werd een experiment opgezet om erachter te komen of we de hypothese dat NVT-leerders meer moeite hebben met standaardvariëteiten die van de virtuele norm afwijken, kunnen bevestigen.

\section{Selectie stimulusmateriaal en opzet experiment}

Om te beginnen werden vier luisterfragmenten geselecteerd uit de examens ${ }^{13}$ van het Certificaat Nederlands als Vreemde Taal (CNaVT), meer bepaald van het C1-profiel Educatief Professioneel (EDUP) en diens voorganger Profiel Academische Taalvaardigheid (PAT). De audiofragmenten werden ingesproken door vier verschillende stemacteurs (twee mannen en twee vrouwen, telkens een Nederlander en een Vlaming) die zich voordoen als wetenschappers en bestrijken verschillende onderwerpen die op een populairwetenschappelijke manier worden gebracht. De ingesproken teksten zijn informatief en/of betogend van aard.

Vervolgens werden colleges met vergelijkbare onderwerpen gezocht in de online databases van de Universiteit van Nederland en Vlaanderen. Deze korte videocolleges worden gegeven door Nederlandse en Vlaamse wetenschappers en zijn bedoeld voor een breed publiek. Ze hebben dus ook een populairwetenschappelijk karakter. Net als in de CNaVT-fragmenten worden vaktermen bijvoorbeeld vermeden of uitgelegd. Bij de selectie werd eveneens gestreefd naar een genderevenwicht en gelijke representatie van de natiolecten. Per onderwerp werden telkens twee tegenhangers van de CNaVT-fragmenten gekozen. Alleen voor een betoog in verband met het universitair onderwijs werd in het corpus van de Universiteit van Nederland en Vlaanderen geen equivalent gevonden en werd voor een ander onderwerp gekozen, zoals in tabel 2 te zien is:

12 Idem.

13 De fragmenten werden met de toestemming van het CNaVT geselecteerd uit de online beschikbare voorbeeldexamens en de takenbank (zie: cnavt.org). 
De verstaanbaarheid van "Standaardnederlandsen" voor vergevorderde NVT-studenten in ...

\begin{tabular}{|c|c|c|c|c|}
\hline bron & onderwerp & geslacht & natiolect & variëteit \\
\hline $\mathrm{CNaVT}$ & (Nederlandse) taalkunde & $\mathrm{V}$ & $\mathrm{BN}$ & $\mathrm{ST}+$ \\
\hline $\mathrm{UvV}$ & (Nederlandse) taalkunde & $\mathrm{V}$ & $\mathrm{BN}$ & $\mathrm{ST}-$ \\
\hline $\mathrm{UvN}$ & (Nederlandse) taalkunde & $\mathrm{M}$ & $\mathrm{NN}$ & $\mathrm{ST}++$ \\
\hline $\mathrm{CNaVT}$ & geneeskunde & $\mathrm{V}$ & $\mathrm{NN}$ & $\mathrm{ST}+$ \\
\hline $\mathrm{UvN}$ & geneeskunde & $\mathrm{V}$ & $\mathrm{NN}$ & $\mathrm{ST}-$ \\
\hline $\mathrm{UvV}$ & geneeskunde & $\mathrm{M}$ & $\mathrm{BN}$ & $\mathrm{ST}-$ \\
\hline $\mathrm{CNaVT}$ & sportpsychologie/-fysiologie & $\mathrm{M}$ & $\mathrm{BN}$ & $\mathrm{ST}+$ \\
\hline $\mathrm{UvV}$ & sportpsychologie/-fysiologie & $\mathrm{M}$ & $\mathrm{BN}$ & $\mathrm{ST}-$ \\
\hline $\mathrm{UvN}$ & sportpsychologie/-fysiologie & $\mathrm{V}$ & $\mathrm{NN}$ & $\mathrm{ST}-$ \\
\hline $\mathrm{CNaVT}$ & universitair onderwijs & $\mathrm{M}$ & $\mathrm{NN}$ & $\mathrm{ST}+$ \\
\hline $\mathrm{UvN}$ & economie/technologie & $\mathrm{V}$ & $\mathrm{NN}$ & $\mathrm{ST}-$ \\
\hline $\mathrm{UvV}$ & economie/technologie & $\mathrm{M}$ & $\mathrm{BN}$ & $\mathrm{ST}-$ \\
\hline
\end{tabular}

Tabel 2 - Overzicht stimulusmateriaal verstaanbaarheids- en distinctietest

De CNaVT-fragmenten bevatten voorgelezen spraak; ook het taalgebruik van de sprekers van de Universiteit van Nederland en Vlaanderen (UvN en UvV, samen Uv) is niet-spontaan want voor de gelegenheid grondig voorbereid voor de video-opname die als open source online beschikbaar is. Aangezien de Uv-colleges voor een groot publiek bedoeld zijn, kunnen we ervan uitgaan dat de sprekers zich de moeite hebben getroost duidelijk verstaanbaar te spreken. Zowel de CNaVT-sprekers als de hoogopgeleide Uv-sprekers hanteren conform de spreeksituatie een standaardvariëteit. Toch is er een verschil tussen de spraak in het CNaVT- en het Uv-corpus.

Het taalgebruik van de Certificaatfragmenten (CNaVT) kan worden gekarakteriseerd als Journaalnederlands of neutrale standaardtaal $(\mathrm{ST}+)$. De Vlaamse stemacteurs houden zich bijvoorbeeld aan de strenge richtlijnen van een keurig Belgisch-Nederlandse uitspraak en diftongeren consequent ei- en ui-klanken. Ook de Nederlandse stemacteurs hebben een verzorgde, niet-regionale uitspraak. De sprekers van de Universiteit van Vlaanderen hebben daarentegen op één na een duidelijk herkenbaar regionaal accent. ${ }^{14}$ De spreker zonder duidelijk aanwijsbaar regionaal accent gebruikt in het geselecteerde fragment in een moment van code-switching evenwel niet-standaardtalige varianten ${ }^{15}$; vandaar dat de variëteit ook in dit geval als ST- wordt aangemerkt. Alle geselecteerde sprekers van de Universiteit van Nederland hebben een uitspraak die in meer of mindere mate als Poldernederlands gekarakteriseerd kan worden, behalve één spreker die juist een geaffecteerde uitspraak heeft (vandaar de aanduiding ST++, die hier voor "superstandaard" staat). ${ }^{16}$

Voor de verstaanbaarheids- en de distinctietest werden telkens twee korte fragmenten van een dertigtal seconden afgebakend, die min of meer een geheel vormen en zonder verdere context begrijpelijk zijn. In beide experimenten werden dus andere fragmenten

14 De BN-fragmenten werden voorgelegd aan em. prof. dr. Magda Devos, die deze analyse onderschreef.

15 In het fragment voor de verstaanbaarheidstest gaat het om t-deletie, zwakke tot afwezige diftongering van ij en $u i$ en progressieve in plaats van regressieve assimilatie (in "dat dan").

16 Dr. Jan Stroop beluisterde de fragmenten en bevestigde deze analyse. 
gekozen uit dezelfde opname. Er werden alleen fragmenten geselecteerd zonder achtergrondgeluid zoals stemmen of applaus uit het publiek. Op vlak van transmissie zijn de fragmenten van het CNaVT en de Uv dus vergelijkbaar.

De twaalf audiofragmenten werden per test in een online formulier in willekeurige volgorde gepresenteerd en in beide experimenten voorafgegaan door twee fragmenten uit de Universiteit van Nederland met een Nederlandse en Vlaamse spreker. Op die manier konden de respondenten vertrouwd raken met de werkwijze en hadden ze een ijkpunt om de andere audiofragmenten te beoordelen.

De studenten kregen de instructie om één keer naar elk fragment te luisteren. Bij het eerste experiment moest de respondenten per audiofragment op een schaal van 1 (= heel slecht verstaanbaar) tot 5 (= heel goed verstaanbaar) aangeven hoe goed zij de spreker konden volgen. Bij deze proef werd dus de gerapporteerde verstaanbaarheid van de proefpersonen getest. Zoals Impe (2010: 8) opmerkt, geeft dit geen objectief beeld van de werkelijke verstaanbaarheid maar het is wel een eenvoudige methode om zicht te krijgen op hoe de respondenten hun eigen verstaanbaarheid inschatten. Bij de distinctietest moesten zij het natiolect van de spreker identificeren. Zij kregen de keuze uit de opties "Nederlands-Nederlands / Noord-Nederlands", "Belgisch-Nederlands / Zuid-Nederlands" en "Ik weet het niet".-

\section{Resultaten verstaanbaarheidstest}

De gerapporteerde verstaanbaarheidsscores lagen gemiddeld hoog (4,4 gemiddeld) wat erop lijkt te wijzen dat de respondenten - vergevorderde NVT-studenten uit de regio Centraal-Europa - over het algemeen weinig verstaanbaarheidsproblemen ondervonden. Toch komen er weldegelijk verschillen naar voren als we de gemiddelde scores groeperen per bron en natiolect, zoals uit figuur 1 blijkt:

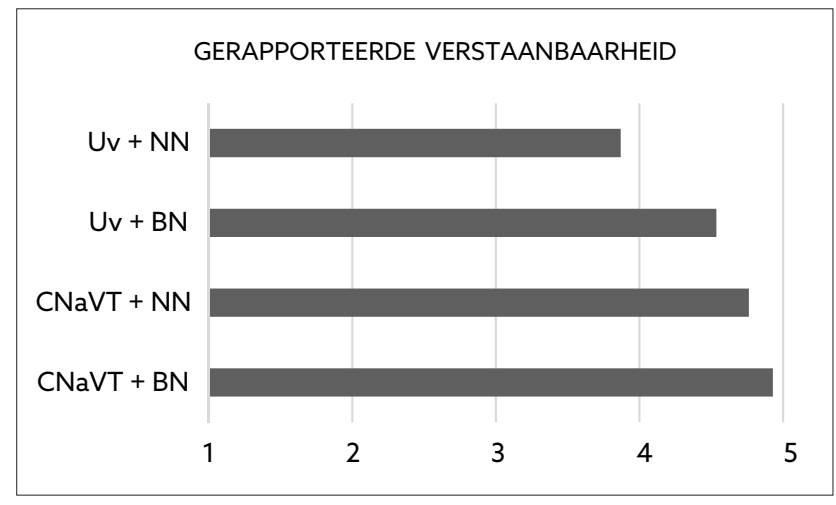

Figuur 1 - Test gerapporteerde verstaanbaarheid: gemiddelde scores op een schaal van 1 tot 5 Uv $=$ Universiteit van Nederland en Vlaanderen; CNaVT = Certificaat Nederlands als Vreemde Taal; NN = Nederlands-Nederlands; $\mathrm{BN}=$ Belgisch-Nederlands. 
De Belgische CNaVT-fragmenten kregen bijna van iedereen de maximumscore, terwijl de fragmenten die het Nederlands-Nederlandse "Lerarennederlands" vertegenwoordigen gemiddeld gezien minder goed verstaanbaar werden ingeschat. Statistisch significant ${ }^{17}$ is het verschil tussen de gemiddelde scores voor de BN- en NN-fragmenten echter niet. Dat is wel het geval als we de gemiddelde scores voor de CNaVT-fragmenten vergelijken met die voor de Uv-fragmenten:

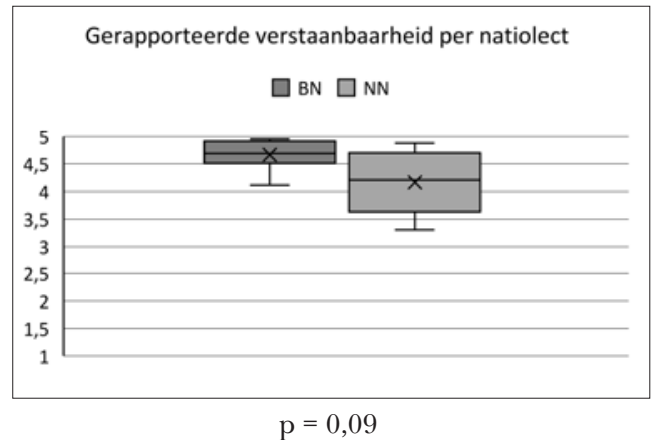

Figuur 2 - Test gerapporteerde verstaanbaarheid: gemiddelde scores op een schaal van 1 tot 5 voor de Belgisch-Nederlandse (BN) en Nederlands-Nederlandse (NN) fragmenten

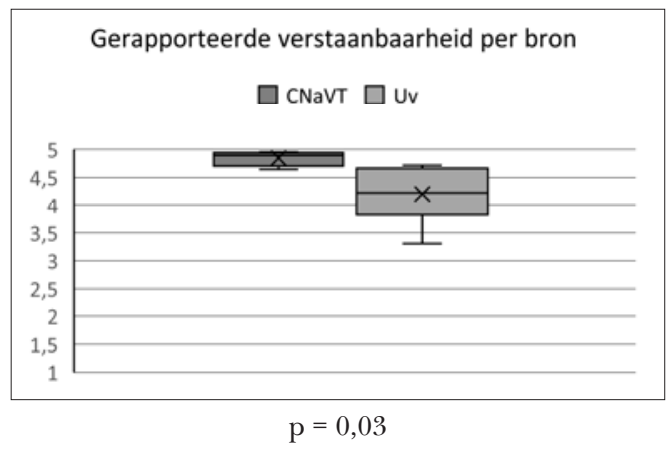

Figuur 3 - Test gerapporteerde verstaanbaarheid: gemiddelde scores op een schaal van 1 tot 5 voor de fragmenten van het Certificaat Nederlands als Vreemde Taal (CNaVT) en de Universiteit van Nederland en Vlaanderen (Uv)

De vraag dringt zich op hoe we die verschillen in verstaanbaarheidsscores kunnen verklaren. Omdat er gewerkt werd met bestaand, niet-gemanipuleerd materiaal is de lexicale moeilijkheidsgraad (het voorkomen van niet-frequente/niet-geleerde woorden) per fragment zeer verschillend. Om na te gaan in hoeverre dit een rol speelt, werden de uitgeschreven fragmenten voorgelegd aan een controlegroep van vier B2-studenten. Zij kregen eerst de opdracht om onbekende woorden aan te duiden (ook als de betekenis uit de context duidelijk was); vervolgens moesten zij twee opgegeven woorden per fragment vertalen. In drie van de vier CNaVT-fragmenten werden een of meer woorden als onbekend aangeduid en/of niet goed vertaald; in de Uv-fragmenten waren er slechts in de helft van de gevallen (én per fragment gemiddeld minder) woorden die problemen opleverden. De lexicale moeilijkheidsgraad lag voor de controlegroep dus hoger bij de CNaVT-fragmenten. Dit lijkt erop te wijzen dat deze factor de verstaanbaarheidsscores niet heeft beïnvloed. ${ }^{18}$

Zoals reeds aangegeven, speelt ook het spreektempo een belangrijke rol bij de verstaanbaarheid. Daarom werd per fragment de spreeksnelheid berekend. Daartoe

17 De verkregen p-waarden van de statistische toetsen worden vermeld onder figuren 2, 3, 4 en 5 . Als grens van statische significantie werd telkens 0,05 genomen.

18 Wegens de geringe omvang van de controlegroep en een gebrek aan waterdichte methode om de moeilijkheidsgraad te berekenen, kunnen hierover uiteraard geen definitieve uitspraken gedaan worden. 
werd het aantal (geïntendeerde) lettergrepen per seconde genomen, inclusief stiltes. ${ }^{19}$ Bij vergelijking van de spreeksnelheid in de geselecteerde CNaVT- en Uv-fragmenten is er geen significant verschil te zien. Hetzelfde geldt voor de BN- en NN-fragmenten in het stimulusmateriaal, zoals onderstaande figuren laten zien:

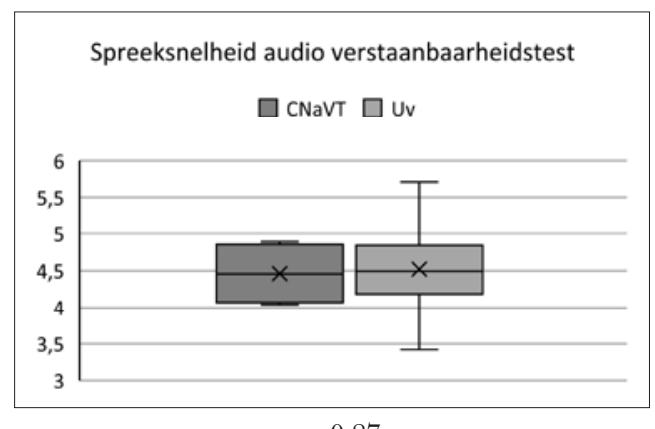

$$
\mathrm{p}=0,87
$$

Figuur 4 - Spreeksnelheid stimulusmateriaal test gerapporteerde verstaanbaarheid in aantal geïntendeerde lettergrepen per seconde: de fragmenten van het Certificaat Nederlands als Vreemde Taal (CNaVT) versus de Universiteit van Nederland en Vlaanderen (Uv)
Spreeksnelheid audio verstaanbaarheidstest

$\square \mathrm{BN} \square \mathrm{NN}$

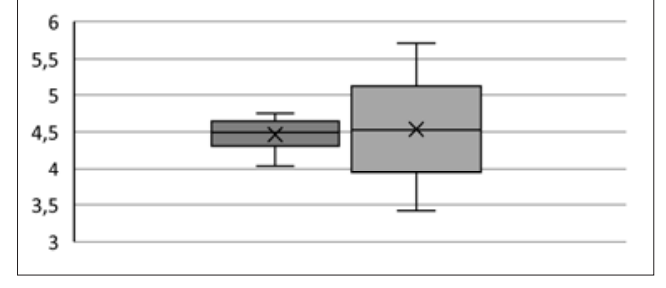

$$
\mathrm{p}=0,84
$$

Figuur 5 - Spreeksnelheid stimulusmateriaal test gerapporteerde verstaanbaarheid in aantal geïntendeerde lettergrepen per seconde: de Belgisch-Nederlandse (BN) versus de Nederlands-Nederlandse (NN) fragmenten

Opmerkelijk is dat de slechtst verstaanbare spreker, althans volgens de gerapporteerde scores, tevens de spreker met de laagste spreeksnelheid is. Het gaat om de spreker met de enigszins geaffecteerde uitspraak $(\mathrm{ST}++)$. De zeer particuliere prosodie (veel sterke zinsklemtonen) die het idiolect van deze spreker kenmerkt, ligt mogelijk aan de basis van de lage scores. Verondersteld kan worden dat eveneens andere prosodiekenmerken ten grondslag liggen aan verstaanbaarheidsproblemen. Ook reductieverschijnselen, die doorgaans minder in voorgelezen spraak voorkomen, zouden het verschil in de scores voor de CNaVT- en Uv-fragmenten kunnen verklaren. Dit zou echter in een ander experiment onderzocht moeten worden.

Hoewel we dus niet kunnen zeggen welke uitspraakkenmerken de verstaanbaarheid het meest beïnvloedden (een regionaal of sociaal accent, reductie- of prosodieverschijnselen), lijken de resultaten onze hypothese te bevestigen: vergevorderde NVT-leerders ervaren meer verstaanbaarheidsproblemen met het zogenaamde "Lerarennederlands" dan het neutrale Standaardnederlands. Omdat het stimulusmateriaal afkomstig is uit niet-gemanipuleerd, authentiek audiomateriaal, en dus grote onderlinge verschillen vertoont, moeten we de resultaten echter met de nodige voorzichtigheid benaderen. Een

19 Vgl. Rosink e.a. (2004: 97): "Spreeksnelheid is een meting van het aantal taaleenheden (fonemen, syllabes, woorden, etc.) dat wordt geproduceerd per tijdseenheid (seconde, minuut, etc.) waarbij stille pauzes worden meegerekend." 
breder opgezet onderzoek met een andere aanpak, waarbij het stimulusmateriaal zo wordt ontworpen dat het aantal variabelen wordt geminimaliseerd, is noodzakelijk om onze conclusies te kunnen staven.

\section{Resultaten distinctiestest}

In een tweede experiment werd gekeken in hoeverre de respondenten Nederlands- en Belgisch-Nederlands juist konden identificeren. Score 1 werd toegekend aan een juiste inschatting van het natiolect. Bij een foute inschatting of het antwoord "Ik weet het niet" werd score 0 toegekend. In figuur $5^{20}$ wordt een overzicht gegeven van de gemiddelde score (uitgedrukt in procent) van de 42 respondenten per fragment:

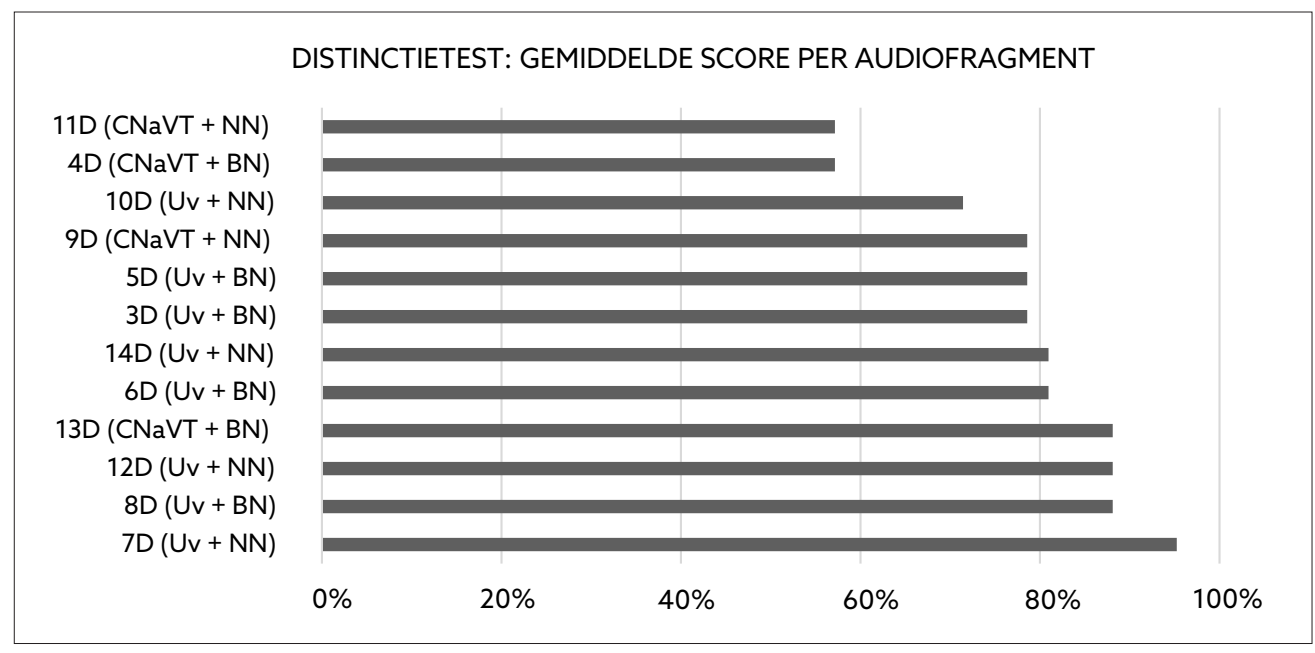

Figuur 5 - Distinctietest: gemiddelde score (correct ingeschatte variëteit) 42 respondenten per audiofragment

Geen enkel fragment kon door alle respondenten juist geïdentificeerd worden als $\mathrm{BN}$ of NN. Opvallend is dat de CNaVT-fragmenten verhoudingsgewijs minder goede resultaten opleverden. Bijna 43 procent van de respondenten wist zich geen raad met CNaVT-fragmenten 11D en 4D of schatten de variëteit verkeerd in. Het spreektempo van de $\mathrm{NN}$-spreekster in 11D ligt erg laag (3,8 lettergrepen per seconde) en de articulatie is zeer duidelijk; er komen weinig of geen reductieverschijnselen in voor. Mogelijk deed dit de respondenten denken aan de "spellingsuitspraak" die kenmerkend is voor het BN-Journaalnederlands. Fragment 4D vertegenwoordigt deze laatste variëteit. Zoals de uitspraaknorm voorschrijft, worden ij-klanken duidelijk gediftongeerd (bijvoorbeeld

20 Net als in de opinietest kregen de respondenten eerst twee fragmenten (1D en 2D) die niet werden meegenomen in het onderzoek. In figuur 5 worden de gemiddelde scores voor de andere fragmenten van laag naar hoog weergegeven. 
in de laatste zin drie keer). Omdat dit in de praktische BN-standaard doorgaans niet gebeurt, verwarden de respondenten daarom misschien de variëteit met NN.

Vier respondenten ${ }^{21}$ werden geïnterviewd om te achterhalen op basis waarvan zij hun keuze voor BN of NN hebben gemaakt. Uit de antwoorden bleek dat de Uv-fragmenten voor deze groep duidelijkere herkenningspunten bevatten, zoals de Gooise $r(\mathrm{NN})$, de harde $\mathrm{g}(\mathrm{NN})$, het gebrek aan diftongering van de lange vocalen $e e$ en oo en tweeklanken ij en $u i(\mathrm{BN})$. De ondervraagde NVT-leerders noemden ook herhaaldelijk de uitspraak van de alveolair s, die in de NN-fragmenten vaak met "retraction"22 (in de oren van de respondenten met een $\int$-achtige klank) wordt uitgesproken. Dit was voor de ondervraagden dus een duidelijke indicatie om het fragment als NN te identificeren. Of dit ook gold voor de andere 38 respondenten kan op basis van dit onderzoek natuurlijk niet gezegd worden.

Tot slot werd er gekeken of respondenten die beter scoorden op de distinctietest, hogere verstaanbaarheidsscores gaven. Men zou immers kunnen veronderstellen dat NVT-leerders die goed bekend zijn met beide natiolecten en deze van elkaar kunnen onderscheiden minder verstaanbaarheidsproblemen ervaren. Voor deze hypothese werd echter geen evidentie gevonden. ${ }^{23}$

\section{Conclusie}

Door diverse onderzoekers werd gepleit voor meer aandacht voor taalvariatie in het NVT-onderwijs. ${ }^{24}$ Hoe de studenten tegenover de verschillende variëteiten van het Nederlands staan, werd echter nog niet uitvoerig onderzocht. Uit een vragenlijst, voorgelegd aan 42 masterstudenten Nederlands uit de regio Centraal-Europa, kwam naar voren dat NVT-leerders het belangrijk vinden dat zowel Nederlands-Nederlands als Belgisch-Nederlands aan bod komt tijdens de lessen NVT. ${ }^{25}$

Aan dezelfde groep werd een test voorgelegd om na te gaan of zij een onderscheid kunnen maken tussen de genoemde natiolecten. De onderlinge verschillen in deze com-

21 Twee moedertaalsprekers van het Tsjechisch en twee moedertaalsprekers van het Slowaaks.

22 Collins \& Mees (2003:190) wijzen erop dat de /s/ door veel sprekers in Nederland, met name in de Randstad, met meer wrijving wordt uitgesproken. Over dit fenomeen is weinig onderzoek beschikbaar. In haar Bachelorproef Regionale variatie in de uitspraak van /s/ in het Nederlands taalgebied concludeert Sanne Ditewig dat de retracted [s] veel vaker voorkomt in Nederland (ook buiten de Randstad) dan in Vlaanderen.

23 Per respondent werd het gemiddelde genomen van de scores bij de opinietest (de inschatting van verstaanbaarheid op een schaal van 1 tot 5) en werd het percentage juiste antwoorden berekend bij de distinctietest. Er blijkt echter geen duidelijk verband tussen beide te bestaan $(R=0,21)$.

24 In een blog vat Steven Delarue (2015) de conclusies van het panelgesprek "Het Nederlands als pluricentrische taal: taalideologische en didactische aspecten" tijdens het IVN-colloquium in Leiden in 2015 als volgt samen: "(1) taalvariatie moet aan bod komen in de NT2-/NVT-klas, (2) de nadruk moet daarbij liggen op bewustmaking, en (3) dat verscherpte taalbewustzijn leidt tot positieve(re) taalattitudes.”

25 De respondenten moesten op een schaal van 1 (niet mee eens) en 5 (helemaal mee eens) de volgende uitspraak beoordelen: "Ik vind het belangrijk dat zowel het Nederlands-Nederlands (Noord-Nederlands) als het Belgisch-Nederlands (Zuid-Nederlands) aan bod komt in de lessen Nederlands." De gemiddelde score was 4,5. 
petentie bleken vrij groot te zijn. ${ }^{26}$ Opvallend was dat de fragmenten uit het CNaVT-corpus, die de "virtuele" standaard vertegenwoordigden, moeilijker te identificeren waren dan het gros van de fragmenten afkomstig uit de colleges van de Universiteit van Nederland en Vlaanderen, waarin de sprekers een variëteit hanteren die meer regionale en sociale variatie laat zien.

In een andere test werd bij dezelfde groep gepeild naar de verstaanbaarheid van verschillende variëteiten in het Standaardnederlands. Daaruit bleek dat de scores voor de BN-fragmenten iets hoger lagen dan voor de NN-fragmenten, maar de resultaten leverden geen significant verschil op. Dat was wel het geval bij een vergelijking van de scores voor de CNaVT-fragmenten en de Uv-fragmenten. De respondenten bleken meer problemen te hebben met de "vitale" standaardvariëteit, wat niet gerelateerd kon worden aan de spreeksnelheid of lexicale moeilijkheidsgraad van de voorgelegde fragmenten. Omdat bij dit experiment gebruik werd gemaakt van een beperkt aantal stimuli, met te veel onderlinge variatie, is vervolgonderzoek nodig om deze bevinding te staven en te achterhalen welke aspecten (onder meer op het gebied van uitspraak en prosodie) verstaanbaarheid bemoeilijken.

Op basis van de voorlopige bevindingen lijkt het evenwel zinvol om in het kielzog van Grondelaers, Van Hout en Van Gent (2016) een onderscheid te maken tussen een "virtuele" en "vitale" standaard binnen het BN en NN. Voor het NVT-onderwijs zou het nuttig zijn om het "Lerarennederlands" (ST-) met behulp van descriptief onderzoek nog beter in kaart te brengen, zowel op vlak van uitspraak als op vlak van (morfo)syntaxis en lexicon. Taalnormeringsboeken en -websites zoals Taaltelefoon en Taaldvies.net, die tegenwoordig weliswaar een pluricentrische visie voorstaan maar toch blijk geven van een sterke gerichtheid op de "virtuele" standaard $(\mathrm{ST}+)$, geven immers een enigszins vertekend beeld van de levendige standaardtaal ${ }^{27}$ en zijn dus slechts beperkt bruikbaar voor de NVT-docent die zijn of haar studenten wil voorbereiden op de taalrealiteit in Nederland en Vlaanderen.

\section{Literatuur}

Absillis, Kevin, Jürgen Jaspers \& Sarah Van Hoof (2012), "Inleiding”. In: Kevin Absillis, Jürgen Jaspers \& Sarah Van Hoof (red.), De manke usurpator. Over Verkavelingsvlaams. Gent: Academia Press, 3-35.

Beheydt, Ludo (2011). "Uitspraakonderwijs Nederlands en normativiteit”. In: Laurent Rasier, Vincent van Heuven, Bart Defrancq \& Philippe Hiligsmann (red.), Nederlands in het perspectief van uitspraakverwerving en contrastieve taalkunde. Gent: Academia Press, 101-118.

Bolten, Afra (2004), “'Zedde zot!'. Vlaamse inburgeringscursisten struikelen over tussentaal”. In: Onze Taal 75-9, 237-238. (online geraadpleegd)

26 Cf. 7 respondenten schatten alle fragmenten goed in; hetzelfde aantal respondenten haalde minder dan $60 \%$.

27 Vgl. De Schryver 2012 die pleit voor "betrouwbare, onderzoeksgebaseerde lijsten" die niet alleen aan beperkte panels met "taalprofessionelen" moeten worden voorgelegd, zoals nu vaak wel het geval is. 
Cajot, José (2012), "Waarom het Verkavelingsvlaams onvermijdelijk was. De ontwikkeling van een informele omgangstaal in Vlaanderen". In: Kevin Absillis, Jürgen Jaspers \& Sarah Van Hoof (red.), De manke usurpator. Over Verkavelingsvlaams. Gent: Academia Press, 39-66.

Collins, Beverley \& Inger M. Mees (2003), The phonetics of English and Dutch. Fifth revised edition. Leiden: Koninklijke Brill NV.

Delarue, Steven (2015), "Nederlands in het NT2- en NVT-onderwijs, maar wélk Nederlands?" (blog), 25 augustus 2010. Op 8 september 2019 geraadpleegd via https://stevendelarue. be/2015/08/25/nederlands-in-het-nt2-en-nvt-onderwijs-maar-welk-nederlands/

Geeraerts, Dirk (2017), "Het kegelspel der taal. De naoorlogse evolutie van de Standaardnederlandsen”. In: Gert De Sutter (red.), De vele gezichten van het Nederlands. Een inleiding tot de variatietaalkunde. Leuven / Den Haag: Acco, 100-120.

Grondelaers, Stefan, Roeland van Hout \& Paul van Gent (2016), "Destandardization is not destandardization. Revising standardness criteria in order to revisit standard language typologies in the Low Countries". In: Taal E Tongual 68 (2), 119-149.

Hiligsmann, Philippe (2010). "Moet Algemeen Nederlands nog steeds als norm fungeren voor het NVT-onderwijs in Franstalig België”. In: Els Hendrickx e.a. (red.), Liever meer of juist minder? Over normen en variatie in taal. Gent: Academia Press, 215-229.

Hoof, Sarah Van en Jürgen Jaspers (2012), "Hyperstandaardisering”. In: TNTL 126 (2), 97-125.

Impe, Leen (2010), Mutual intelligibility of national and regional varieties of Dutch in the Low Countries. Ongepubliceerd proefschrift, KU Leuven. (online geraadpleegd)

Kloots, Hanne \& Steven Gillis (2012), "Bang voor Babel. De verstaanbaarheid van tussentaal”. In: Kevin Absillis, Jürgen Jaspers \& Sarah Van Hoof (red.), De manke usurpator. Over Verkavelingsvlaams. Gent: Academia Press, 225-244.

Lybaert, Chloé (2016), "Moet tussentaal een (grotere) plaats krijgen in lessen Nederlands voor nieuwkomers?”. In: Over taal 55 (3), 6-8. (online geraadpleegd)

Schryver, Johan De (2012), "Het einde van de tussentaal en de Vlaamse standaardtaaldiscussie". In: Kevin Absillis, Jürgen Jaspers \& Sarah Van Hoof (red.), De manke usurpator. Over Verkavelingsulaams. Gent: Academia Press, 141-165.

Rosink, Susan e.a. (2014), "De verstaanbaarheid van natuurlijk snelle versus kunstmatig versnelde spraak in het Nederlands". In: Dutch Journal of Applied Linguistics 3 (2), 197-210. (online geraadpleegd)

\section{Bronnen stimulusmateriaal:}

Certificaat Nederlands als Vreemde Taal: Voorbeeldexamens Educatief Professioneel. Op 15 januari 2019 geraadpleegd via http://cnavt.org/voorbereiding/voorbeeldexamens\#5

Certificaat Nederlands als Vreemde Taal: Takenbank voor docenten. Op 15 januari 2019 geraadpleegd via http://cnavt.org/takenbank

Universiteit van Nederland. Op 15 januari 2019 geraadpleegd via https://universiteitvannederland.nl/

Universiteit van Vlaanderen. Op 15 januari 2019 geraadpleegd via https://www.universiteitvanvlaanderen.be/ 
Lic. Sofie Royeaerd, M.A. / 103711@mail.muni.cz

Masarykova univerzita, Filozofická fakulta, Ústav germanistiky, nordistiky a nederlandistiky, Arna Nováka 1, 60200 Brno, CZ 